Witold M. Orłowski*

\title{
Konkurencyjność gospodarcza krajów. Propozycja alternatywnego pomiaru w kontekście dyskusji o konkurencyjności polskiej gospodarki
}

\begin{abstract}
The economic competitiveness of countries. An alternative proposal of its measurement in the context of the competitiveness of Polish economy: This article looks at the problem of measuring economic competitiveness of countries. It begins with describing various definitions of this phenomenon which are sometimes quite vague and close to tautology. The indicators of competitiveness which are most commonly used lack theoretical background, while the results depend on arbitrary choice of variables used for their construction. The author makes a proposal of an alternative way of measuring the competitiveness which is simple and well rooted in the theory. However, given the complexity of the problem, the proposed measurement does not solve all the problems. Its results allow for making the assessment of the development model of Poland and, in particular, formulating a hypothesis that Poland is underperforming in the field of the competitiveness given its level of economic and institutional development.
\end{abstract}

Słowa kluczowe: konkurencyjność gospodarki narodowej, konkurencyjność międzynarodowa, pomiar konkurencyjności, gospodarcza konkurencyjność Polski

Keywords: competitiveness of national economy, international competitiveness, measurement of competitiveness, economic competitiveness of Poland

* Profesor doktor hab., rektor Akademii Finansów i Biznesu Vistula; e-mail: witold.orlowski@vistula.edu.pl.

\section{Wstęp}

Pojęcie konkurencyjności jest jednym z najczęściej używanych określeń związanych z oceną stanu gospodarki narodowej, jej perspektyw rozwoju i skuteczności prowadzonej polityki gospodarczej. Jest również szeroko wykorzystywane w debacie politycznej i analizie ekonomicznej (zarówno krótkookresowej, jak długookresowej). Jednocześnie jednak - co zdumiewające - jest określeniem 
niemającym jednoznacznej, powszechnie przyjętej przez nauki ekonomiczne definicji. Jest więc bardziej pojęciem intuicyjnym niż jasno sprecyzowanym, co utrudnia zarówno analizę, jak pomiar.

Celem niniejszego artykułu jest przypomnienie stosowanych definicji konkurencyjności, wraz ze wskazaniem wiążących się z nimi kontrowersji, a następnie zaprezentowanie alternatywnego sposobu pomiaru. $\mathrm{W}$ artykule podjęto również niezwykle istotny temat różnic pomiędzy krótkookresowymi zmianami konkurencyjności, a konkurencyjnością w dłuższym okresie, m.in. na podstawie doświadczeń krajów Unii Europejskiej z lat poprzedzających kryzys finansowy oraz w czasie samego kryzysu.

\section{Dawne i współczesne definicje konkurencyjności}

Nawet stosunkowo skromny przegląd literatury pokazuje, że istnieje bardzo wiele prób zdefiniowania, na różne sposoby, pojęcia konkurencyjności. Przykładowo, jedno z przeglądowych opracowań cytuje 20 różnych definicji, nie roszcząc sobie bynajmniej pretensji do pełnego zestawienia ${ }^{1}$. Można się wręcz spotkać z poglądem, że pojęcie to w ogóle nie ma praktycznego sensu i jest jedynie odbiciem pojęcia produktywności².

Problem częściowo bierze się z tego, że konkurencyjność może mieć znaczenie zarówno mikroekonomiczne (konkurencyjność przedsiębiorstwa), jak i makroekonomiczne (konkurencyjność gospodarki). Pojęcie konkurencyjności na poziomie przedsiębiorstwa nie wiąże się z większymi kontrowersjami - mimo różnych konkretnych definicji, zazwyczaj jest ono utożsamiane z jego zdolnością do produkowania i dostarczania na rynek produktów lepszych i tańszych od konkurentów (a więc produkowanych po niższym koszcie lub sprzedawanych - dzięki np. skutecznemu marketingowi albo większej innowacyjności produktów - z większą marżą wartości dodanej). Oczekiwanym efektem wysokiej konkurencyjności przedsiębiorstwa jest zwiększanie udziału w rynku i zysków³ Konkurencyjność w sensie makroekonomicznym jest próbą uogólnienia tego pojęcia na całość gospodarki ${ }^{4}$ Należy jednak pamiętać, że pojawiają się wów-

1 Zob. T. Siudek, A. Zawojska, Competitiveness in the economic concepts, theories and empirical research, „Acta Scientiarum Polonorum. Oeconomia” 2014, nr 13(1), s. 93-95.

2 Zob. P. Krugman, Making Sense of the Competitiveness Debate, „Oxford Review of Economic Policy" 1996, nr 12(3), s. 17-18; M. Porter, C. Ketels, M. Delgado, The Microeconomic Foundations of Prosperity: Findings from the Business Competitiveness Index [w:] The Global Competitiveness Report 2007-2008, World Economic Forum, Geneva 2008, s. 52.

3 Zob. M.J. Radło, Międzynarodowa konkurencyjność gospodarki. Uwagi na temat definicji, czynników i miar, Oficyna Wydawnicza SGH, Warszawa 2008, s. 3.

${ }^{4}$ Zob. D.W. Jorgenson, M. Kuroda, Productivity and International Competitiveness in Japan and the United States, 1960-1985 [w:] red. B.G. Hickman, International Productivity and Competitiveness, Oxford University Press, New York 1992, s. 30. 
czas poważne problemy interpretacyjne: w skali całej gospodarki poziom cen, po jakim oferuje się towary na rynkach światowych, nie jest wcale parametrem zewnętrznym (jak to jest dla przedsiębiorstwa). Na poziom cen i kosztów państwo oddziaływać może za pośrednictwem różnego typu instrumentów, a przede wszystkim za pośrednictwem kursu walutowego. Wobec tego zawodzi intuicyjnie oczywisty związek między konkurencyjnością kraju a zwiększaniem udziału w światowym rynku lub wypracowywaniem nadwyżki handlowej, gdyż czynniki te nie zależą wyłącznie od konkurencyjności ${ }^{5}$.

Poszukiwanie związków pomiędzy konkurencyjnością kraju a wynikami osiąganymi na rynku światowym jest dość naturalną próbą przeniesienia na poziom makroekonomiczny tego, co wydaje się oczywiste na poziomie przedsiębiorstwa. Odległych źródeł takiego podejścia można szukać jeszcze w XVII-XVIII-wiecznym merkantylizmie, uważającym za główne zadanie polityki gospodarczej doprowadzenie do nadwyżki handlowej, która zapewniała (w czasach waluty kruszcowej) napływ do kraju metali szlachetnych i przyspieszony rozwój gospodarczy (oczywiście kosztem innych krajów, które kruszce traciły). Rozwój teorii ekonomii spowodował, że od czasów XIX-wiecznego angielskiego ekonomisty Davida Ricardo przekonanie o konieczności wypracowania bezwzględnej przewagi konkurencyjnej (czyli jak największej nadwyżki handlowej w stosunku do rywali, nawet za cenę dławienia importu) zastąpione zostało przez teorię przewag względnych (komparatywnych), według której kraj powinien starać się uzyskać przewagę konkurencyjną jedynie w odniesieniu do tej części produkcji, w której się z różnych powodów specjalizuje (np. ze względu na warunki naturalne i posiadane zasoby). Dalszy rozwój wiedzy, a w szczególności powstanie w latach 30. XX wieku teorii handlu Heckschera-Ohlina, wskazywał na to, że elementem powodującym specjalizację handlową kraju jest zaopatrzenie w czynniki produkcji (pracę i kapitał), determinujące uzyskanie wysokiej konkurencyjności w odniesieniu do produktów pracochłonnych lub kapitałochłonnych. Głównym wnioskiem wyniesionym z rozwijającej się teorii handlu było generalne stwierdzenie, że konkurencyjności kraju nie należy utożsamiać z ogólnym dodatnim saldem handlowym, a sens ma jedynie badanie tzw. ujawnionych przewag konkurencyjnych w zakresie poszczególnych grup towarów ${ }^{6}$. Wymiana międzynarodowa nie jest bowiem grą o zerowej sumie wypłat, jej wzrost może przynosić korzyści obu stronom, nawet jeśli jedna z nich odnotowuje deficyt, a saldo handlowe jest efektem oddziaływania również in-

5 Zob. W.M. Orłowski, Makroekonomiczne przyczyny deficytu obrotów bieżących [w:] Bilans płatniczy Polski. Wyzwania i zagrożenia, red. U. Płowiec, W.M. Orłowski, Bellona, Warszawa 1999, s. 22-23.

${ }^{6}$ R. Voinescu, C. Moisoiu, Competitiveness, Theoretical and Policy Approaches. Towards a more competitive EU, „Procedia Economics and Finance” 2015, nr 22, s. 514-517, https:// doi.org/10.1016/s2212-5671(15)00248-8. 
nych czynników ${ }^{7}$ Mogą one powodować, że kraj wysoce konkurencyjny odnotowuje deficyt (tak np. dzieje się od niemal czterech dekad w przypadku USA), a kraj o stosunkowo niskiej konkurencyjności systematycznie wypracowuje nadwyżkę (takim przykładem jest Rosja). Warto przy tym zauważyć, że choć ekonomia dawno odrzuciła przekonanie o tym, że wymiana międzynarodowa jest grą o zerowej sumie wypłat, w której korzyści osiąga się tylko w przypadku wypracowania nadwyżki handlowej, uwaga taka nie odnosi się do polityki, o czym mogą świadczyć np. liczne wypowiedzi na tematy handlowe prezydenta Donalda Trumpa ${ }^{8}$.

Choć definicje odwołujące się do salda handlowego (w bardziej lub mniej jawny sposób) wcale nie zniknęły z analiz ekonomicznych ${ }^{9}$, to od co najmniej pół wieku dominuje próba zdefiniowania konkurencyjności krajów. Odbywa się ona albo poprzez stwierdzenie, że jest to zdolność gospodarki do rywalizacji na światowych rynkach, a w szczególności do sprzedaży własnych towarów i usług na tych rynkach, przy zastrzeżeniu, że sprzedaż ta musi prowadzić do wzrostu dochodów i poziomu życia mieszkańców (a więc nie np. na ekstensywnej eksploatacji zasobów naturalnych ${ }^{10}$ ), albo poprzez określenie jej po prostu jako zdolności do utrzymania długookresowego wzrostu gospodarczego i wysokiego poziomu życia mieszkańców kraju poprzez odpowiednie zarządzanie zasobami i procesami, przy zastrzeżeniu, że odbywa się to na konkurencyjnym światowym rynku $^{11}$. Bardziej rozbudowane definicje precyzują, że wysoka konkurencyjność oznacza umiejętność stworzenia instytucji, zarządzania zasobami, pobudzenia innowacyjności i prowadzenia takiej polityki gospodarczej, która umożliwia wzrost produktywności i długookresowy rozwój ${ }^{12}$. Takie podejście pasuje znacznie bardziej do współczesnej wiedzy ekonomicznej. Budzi jednak kontrowersje innego rodzaju: oznacza bowiem, że pojęcie konkurencyjności jest w gruncie rzeczy tylko innym sposobem nazwania zasadniczego celu polityki gospodarczej, jakim jest długookresowy wzrost, może więc być uznane za całkowicie zbędne

7 Zob. W.M. Orłowski, Makroekonomiczne przyczyny deficytu, op. cit., s. 24.

8 Zob. K. Gittleson, US trade: Is Trump right about the deficit?, BBC News, 2018, https:// www.bbc.com/news/world-43336599 [dostęp: 22 lipca 2018 r.].

9 Zob. M. Porter, C. Ketels, M. Delgado, The Microeconomic Foundations of Prosperity, op. cit., s. 52.

10 Zob. L. D'Andrea Tyson, Who's Bashing Whom: Trade Conflict in High Technology Industries, Institute for International Economics, Washington 1992, s. 5-6.

11 Zob. P. Annoni, L. Dijkstra, N. Gargano, The EU Regional Competitiveness Index 2016, European Commission Working Papers WP 02/2017, s. 2.

12 Zob. J. Bossak, Międzynarodowa konkurencyjność gospodarki polskiej - ujęcie instytucjonalne [w:] Konkurencyjność gospodarki polskiej a rola państwa przed akcesja do Unii Europejskiej, red. H. Podedworny, J. Grabowiecki, H.Wnorowski, Uniwersytet w Białymstoku, Białystok, 2000 s. 38, oraz World Economic Forum, The Global Competitiveness Report 2017-2018, red. X. Sala-i-Martín, K. Schwab, World Economic Forum, Geneva 2017, s. 2-5. 
$\mathrm{w}$ analizie ${ }^{13}$. Można wręcz twierdzić, że tak rozumiane określenie „konkurencyjność" mieści się bardziej w sferze publicystyki ekonomicznej niż ekonomii.

\section{Dylematy pomiaru konkurencyjności}

Pomiar konkurencyjności krajów odbywać się może na dwa sposoby. Jednym jest poszukiwanie wskaźnika konkurencyjności ex ante, pozwalającego prognozować bardziej pomyślny rozwój tych krajów, które są bardziej konkurencyjne. Drugim jest poszukiwanie wskaźnika konkurencyjności ex post, a więc ujawnionej w pewien sposób przewagi konkurencyjnej, która pozwoliła na taki rozwój ${ }^{14}$.

Po odrzuceniu poglądów, że konkurencyjność można w stosunkowo łatwy sposób zmierzyć ex post za pomocą prostych charakterystyk handlu zagranicznego (takich jak np. saldo handlowe, udział w światowym eksporcie, eksport per capita, terms of trade), podjęto liczne próby pomiaru za pomocą zmiennych makroekonomicznych ściśle powiązanych ze wzrostem gospodarczym (takich jak PKB per capita, produktywność, realny dochód per capita, realny kurs walutowy, poziom jednostkowych kosztów pracy, poziom konkurencyjności technologicznej aproksymowany wydatkami na $\mathrm{B}+\mathrm{R})^{15}$. Miary takie pasują do współczesnych poglądów na problemy konkurencyjności, tworzą jednak oczywisty dylemat podważający sens badań: skoro konkurencyjność jest rozumiana jako warunek wzrostu na globalnym rynku, to jej pomiar za pomocą uzyskanych wskaźników wzrostu staje się tautologią (zakładamy, że skoro kraj rozwijał się szybciej, to z definicji znaczy, że był bardziej konkurencyjny; po co w takim razie mierzyć konkurencyjność, skoro możemy bezpośrednio mierzyć wzrost?).

Alternatywą dla tego podejścia jest poszukiwanie miar określających konkurencyjność ex ante. Najbardziej popularnym obecnie kierunkiem badań jest konstrukcja zagregowanych wskaźników, opisujących zasoby kraju, sposoby zarządzania tymi zasobami, zaawansowanie technologiczne i jakość instytucji (zależną często również od głęboko ukrytych „czynników miękkich” leżących u podstaw rozwoju, np. czynników o charakterze kulturowym) $)^{16}$.

Najbardziej znanymi wskaźnikami tego typu są: The Global Competitiveness Index publikowany przez Światowe Forum Ekonomiczne (WEF, World Economic Forum) oraz World Competitiveness Scoreboard publikowany przez

13 Zob. P. Krugman, Making Sense of the Competitiveness Debate, op. cit., s. 17.

${ }_{14}$ Zob. J. Mróz, Determinanty i miary międzynarodowej konkurencyjności gospodarki [w:] Ekonomia i zarządzanie w teorii i praktyce, t. 9, red. P. Urbanek, E. Walińska, Wydawnictwo Uniwersytetu Łódzkiego, Łódź 2016, s. 16-17.

15 Przegląd miar zawiera opracowanie: T. Siudek, A. Zawojska, Competitiveness in the economic concepts, op. cit.

16 Zob. A. Wojtyna, O badaniach nad „głębszymi” przyczynami wzrostu gospodarczego [w:] Wzrost gospodarczy w krajach transformacji. Konwergencja czy dywergencja?, red. R. Rapacki, PWE, Warszawa 2009, s. 188. 
International Institute for Management Development (IMD). Oba wskaźniki są średnimi ważonymi z licznych wskaźników, zagregowanych z użyciem przyjętych w sposób uznaniowy wag, oba służą do sporządzenia rankingu konkurencyjności krajów.

Wskaźnik WEF grupuje wskaźniki w 12 obszarach (filarach konkurencyjności). Filary te są następujące: (1) instytucje, (2) infrastruktura, (3) środowisko makroekonomiczne, (4) zdrowie i podstawowa edukacja, (5) wyższa edukacja i szkolenie, (6) efektywność rynku towarów, (7) efektywność rynku pracy, (8) rynek finansowy, (9) gotowość do absorbcji technologii, (10) wielkość rynku, (11) „wyrafinowanie" biznesowe, (12) innowacyjność ${ }^{17}$.

Każdy ze wskaźników cząstkowych (dla „filarów”) liczony jest jako średnia ważona wielu wybranych a priori wskaźników szczegółowych, tak że łącznie mamy do czynienia ze średnią ważoną ponad 100 wskaźników, normalizowanych według skali od 1 do 7 , z których znaczna część pochodzi ze specjalnego badania opinii menedżerów światowych firm. Wskaźnik jest obecnie wyliczany dla 137 krajów, wahając się w edycji na lata 2017-2018 pomiędzy najniższą wartością 2,87 w Jemenie a 5,86 w zajmującej pierwsze miejsce Szwajcarii (teoretycznie wskaźnik może kształtować się pomiędzy 1 a 7).

Z kolei wskaźnik IMD grupuje wskaźniki według czterech obszarów („czynników konkurencyjności”). Są to: (1) wyniki gospodarcze, (2) efektywność rządu, (3) efektywność biznesu, (4) infrastruktura ${ }^{18}$.

Podobnie jak we wskaźniku WEF, każdy ze wskaźników cząstkowych (dla „Czynników”) liczony jest jako średnia ważona wybranych a priori wskaźników szczegółowych. Łącznie używa się 340 wskaźników, z czego $1 \frac{1}{3}$ pochodzi z badania opinii menedżerów światowych firm. Wskaźnik WEF jest obecnie wyliczany dla 63 krajów, wahając się w edycji na rok 2018 pomiędzy najniższą wartością 27,5 w Wenezueli, a 100,0 w zajmujących pierwsze miejsce USA (teoretycznie wskaźnik może kształtować się pomiędzy 0 a 100, przy czym wartość 100 osiąga kraj najlepiej wypadający w badaniu).

Nie ma wątpliwości, że oba wskaźniki wyliczane są w sposób staranny i oparte są na ogromnym materiale statystycznym. Są one też powszechnie stosowane dla różnego typu analiz, a także w dyskursie publicznym. Należy jednak zwrócić uwagę na fakt, że skonstruowane w taki sposób mierniki konkurencyjności nie są oparte na jasnym modelu teoretycznym i nie podlegają żadnej weryfikacji - zmiana zestawu wskaźników albo zmiana użytych wag prowadzą do zmiany wartości całego miernika, bez możliwości jakiejkolwiek weryfikacji sensowności dokonania takiej zmiany. Można też zauważyć, że przyjęcie nie-

17 Zob. World Economic Forum, The Global Competitiveness Report 2017-2018, op. cit., s. 317-324.

18 Zob. International Institute for Management Development, World Competitiveness Yearbook 2017, IMD Publishing, Lausanne 2017, s. 174-178. 
co innego zestawu wskaźników i wag bardzo różnicuje wyniki uzyskane przy konstrukcji miernika WEF i IMD - przykładowo, sklasyfikowane na dość odległym 27. miejscu w rankingu WEF Chiny w rankingu IMD są na miejscu 13., a sklasyfikowana na miejscu 9. Japonia jest w rankingu IMD na miejscu 25. Oba wskaźniki dokonują pomiaru ex ante, a nie ex post, i są to wskaźniki nakładu, a nie wyniku - wskazują na to, w jakim stopniu kraj jest teoretycznie przygotowany do konkurencyjnej walki, przygotowanie prowadzi do efektów w postaci lepszego rozwoju. Ich złożona struktura nie pozwala na jednoznaczną analizę ich teoretycznego związku z rzeczywistą konkurencyjnością. Nie oznacza to oczywiście, że nie są one użyteczne, ale ich przydatność do oceny rzeczywistej konkurencyjności jest ograniczona.

Warto w tym miejscu przyjrzeć się temu, w jaki sposób poziom zagregowanych mierników konkurencyjności wiąże się ze zmiennymi makroekonomicznymi, które mogą być kojarzone z ujawnioną konkurencyjnością (oczywiście pamiętając o tym, że zdaniem Autora żaden z zaproponowanych dotychczas wskaźników ujawnionej konkurencyjności nie może być uznany za satysfakcjonujący). Dane dotyczące krajów zajmujących najwyższe 10 pozycji w rankingach konkurencyjności WEF i IMD (uporządkowane według miejsc zajmowanych w rankingu WEF) i dla porównania Polski zawiera tabela 1.

Warto przede wszystkim zauważyć, że znaczne różnice występują w samych rankingach WEF i IMD. Przytoczone w tabeli 1 dane pokazują też, że brak jest wyraźnego związku między ocenami konkurencyjności ex ante, a wynikami odnotowanymi w handlu zagranicznym. Wśród krajów z czołówki rankingu są zarówno gospodarki z trwale wysokim saldem dodatnim (Singapur, Zjednoczone Emiraty Arabskie, Szwajcaria, Holandia i Niemcy), jak i kraje z saldem wyraźnie ujemnym (USA, Wielka Brytania, Kanada). Wiąże się to z dwoma zjawiskami. Po pierwsze, dane handlowe dotyczące przepływu towarów nie uwzględniają ważnych wielu przepływów o charakterze bieżącym, które obok salda handlowego wpływają na saldo obrotów bieżących (np. salda przepływu usług, w tym również usług czynników produkcji). Po drugie jednak - i ważniejsze - na kształtowanie się salda handlowego i salda obrotów bieżących poważny wpływ mają czynniki makroekonomiczne inne niż konkurencyjność. Na przykład w USA ujemne saldo wymuszone jest przez utrzymujący się od lat 80 . ogromny import kapitału, prowadzący do umocnienia się kursu walutowego i do wzrostu importu ${ }^{19}$.

Potwierdza to generalną tezę, że brak jest ścisłego związku między współczesnym rozumieniem konkurencyjności, a odziedziczonym z odległej przeszłości i popularnym w debacie publicznej przekonaniem, że jej wynikiem musi być dodatnie saldo w wymianie z zagranicą. Choć rzeczywiście większość krajów z czołówki obu rankingów odnotowuje nadwyżkę, to jednak większą nadwyżką

19 Zob. W.M. Orłowski, Świat do przeróbki, Agora, Warszawa 2011, s. 186 


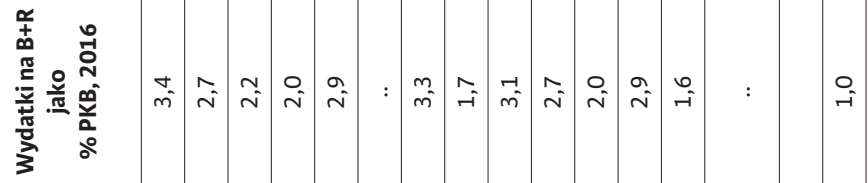

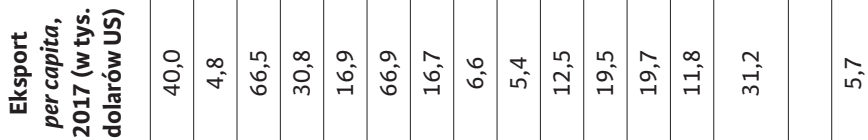

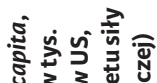

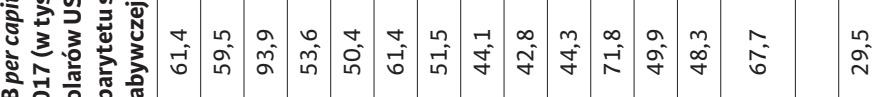

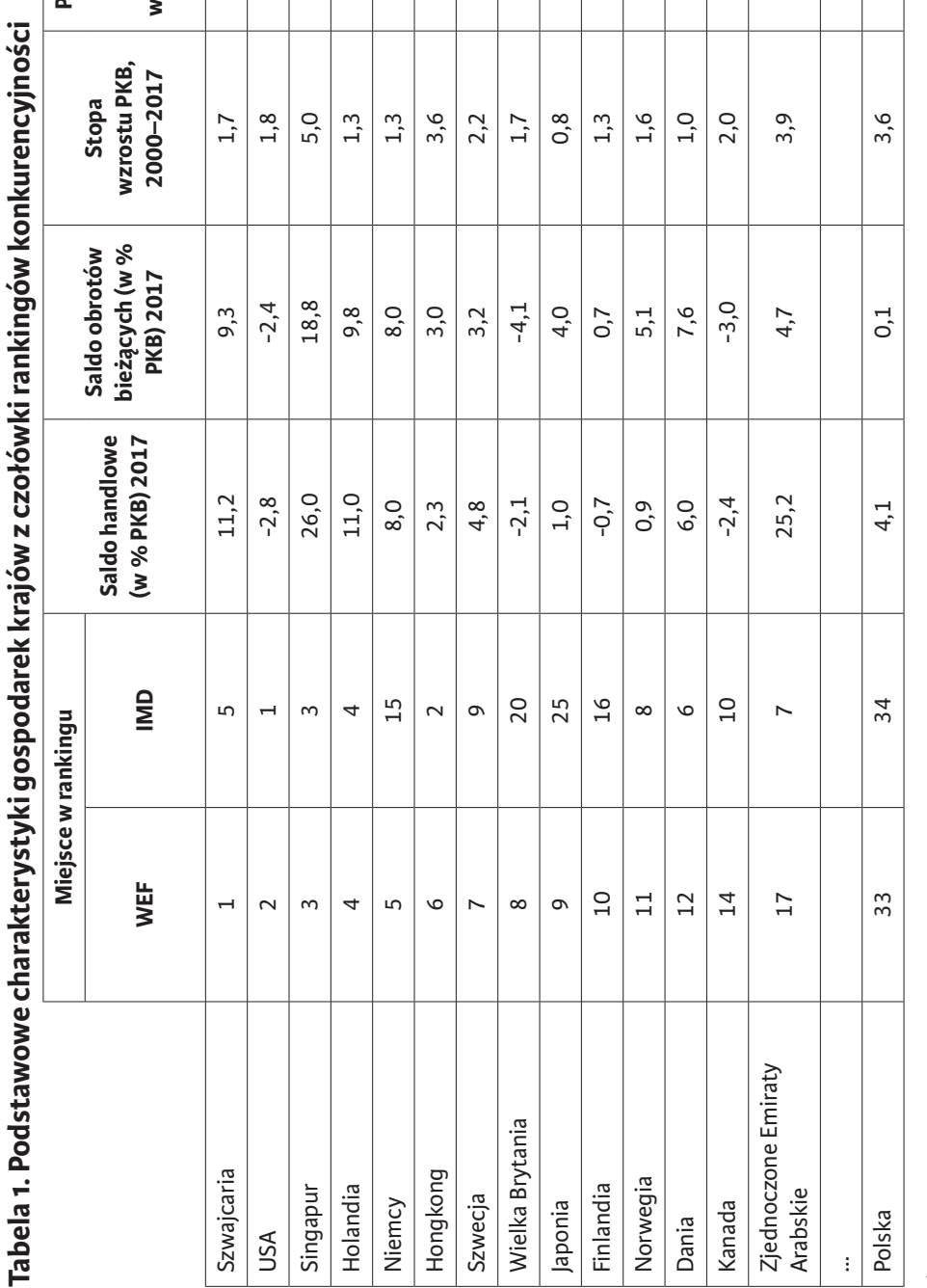

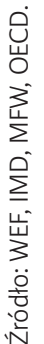


eksportu od Szwajcarii charakteryzuje się np. zajmujące 46. miejsce w rankingu WEF Brunei (11,9\% PKB nadwyżki), a zbliżony poziom odnotowują zajmujące 60. miejsce Węgry (10,1\% PKB nadwyżki). Można również odnotować, że stosunkowo wysoką nadwyżkę handlową odnotowuje w ostatnich latach Polska.

Warto też zauważyć, że kraje z czołówki obu rankingów charakteryzują się wysokim poziomem PKB na głowę mieszkańca (3,4 razy wyższym od średniej światowej i o 16\% wyższym od średniej krajów wysoko rozwiniętych), poza Singapurem nie wyróżniają się natomiast wysokim tempem wzrostu PKB (jest ono, poza Singapurem, niższe od średniego tempa wzrostu PKB na świecie osiągającego w latach 2000-2017 poziom 3,9\%). Jest to zresztą zgodne z teorią wzrostu, według której kraje zamożniejsze rozwijają się w zasadzie wolniej od krajów uboższych ${ }^{20}$. Nie istnieje również prosta zależność wiążąca konkurencyjność kraju z wielkością eksportu (kraje o większej ludności i gospodarce mają zazwyczaj niższą relację eksportu do $\mathrm{PKB}$ ) ani z wydatkami na badania i rozwój $(\mathrm{B}+\mathrm{R})$, choć niewątpliwie kraje z czołówki obu rankingów charakteryzują się stosunkowo wysokim poziomem tych wydatków.

\section{Alternatywny pomiar poziomu konkurencyjności}

Analizując dotychczas zgłaszane propozycje pomiaru poziomu konkurencyjności krajów, można dojść do wniosku, że w znacznej mierze nie spełniają one oczekiwań. W przypadku powszechnie dziś używanych mierników zagregowanych brak jest jednoznacznej podstawy teoretycznej konstrukcji, uzyskane wyniki są niestabilne ze względu na arbitralność przyjętego zestawu danych i wag użytych do agregacji, a wysoki stopień skomplikowania uniemożliwia logiczną weryfikację związku miernika z mierzonym zjawiskiem. Mierniki oparte na wynikach handlowych całkowicie zawodzą, ze względu na to, że nie są w stanie uwzględnić wpływu na handel innych niż konkurencyjność czynników makroekonomicznych i rynkowych. Mierniki oparte na pomiarze produktywności lub PKB per capita grożą tautologicznym zapętleniem się analizy. Z kolei mierniki oparte na wybranych elementach przewagi konkurencyjnej (np. na innowacyjności i przewadze technologicznej), choć często mają walor prostoty i elegancji pomiaru, w oczywisty sposób mają też charakter cząstkowy i nie obejmują całości problemu.

Aby zaproponować miarę alternatywną, w pewnym stopniu wolną od powyższych wad, przyjmijmy najpierw dość powszechnie akceptowaną definicję, że przez konkurencyjność kraju rozumiemy jego zdolność do trwałego zapewnienia wysokiego poziomu dochodów mieszkańcom, dzięki udziałowi w światowym rynku i zdolności do sprzedawania na nim konkurencyjnych towarów

20 Zob. D.W. Jorgenson, M. Kuroda, Productivity and International Competitiveness, op. cit., s. 30-31. 
(sprzedawanych taniej dzięki niższym kosztom produkcji lub przynoszących wyższą marżę wartości dodanej).

W następnym kroku rozważmy, jakiego typu zjawiska będą charakterystyczne dla kraju, który uzyskał wysoką konkurencyjność (mowa tu o konkurencyjności ujawnionej, czyli mierzonej ex post). Po pierwsze, jeśli mówimy o kraju, który zapewnia swoim obywatelom wysoki poziom dochodów, możliwość sprzedaży towarów taniej od konkurentów pojawia się jedynie w sytuacji, gdy w sektorze eksportowym mamy do czynienia z bardzo wysokim poziomem wydajności pracy (głównie dzięki stosowaniu technik pracooszczędnych, a w obecnym świecie w szczególności dzięki wykorzystaniu zjawisk cyfryzacji i robotyzacji produkcji). Po drugie, możliwość sprzedaży z wyższą od konkurentów marżą wartości dodanej pojawia się w przypadku produkcji innowacyjnej, sprzedawanej pod własną marką, wspartej odpowiednim marketingiem, a więc lokującej się w górnym obszarze łańcucha wartości ${ }^{21}$. Po trzecie wreszcie, trwałe wykorzystanie tych przewag dzięki udziałowi w światowym rynku jest możliwe jedynie w przypadku gospodarki otwartej, charakteryzującej się wysoką efektywnością rynków, dobrze zarządzanej i wyposażonej w sprzyjające rozwojowi instytucje.

Gospodarka, która miałaby te trzy cechy, w dynamicznym procesie podnoszenia konkurencyjności doświadczałaby zjawiska polegającego na coraz wyższej rynkowej wycenie jednostki jej pracy zaangażowanej w produkcję dokonywanej przez rynek światowy. Wzrost konkurencyjności oznaczałby więc szybszy wzrost bieżącej światowej wyceny pracy od krajowego wzrostu jej wartości, a wysoki poziom konkurencyjności kraju oznaczałby trwale wysoką relację wyceny pracy przez rynek światowy w stosunku do rynku krajowego.

Kluczowym parametrem, za pomocą którego rynek światowy może dokonać wyceny wartości jednostki pracy w danym kraju, jest bieżący kurs walutowy (wzrost wyceny tej wartości, czy to ze względu na zwiększenie produktywności, czy wzrost marży wartości dodanej, powoduje realną aprecjację waluty, a w ślad za tym wzrost płac wyrażonych $w$ walucie międzynarodowej) $)^{22} . Z$ kolei realna wycena wartości pracy przez rynek krajowy odbywa się poprzez rzeczywistą siłę nabywczą płac, a jej odbiciem w porównaniach $\mathrm{z}$ innymi krajami jest kurs wyznaczany według parytetu siły nabywczej walut (kurs wyznaczany w ten sposób nie bierze pod uwagę różnic w cenach dóbr między krajami, a więc jego zmiana wynika jedynie ze zmian wydajności pracy) ${ }^{23}$.

Skoro tak, to odniesienie rynkowego kursu walutowego do kursu wyliczanego według realnej siły nabywczej jednostki waluty powinno informować nas o ujawnionej konkurencyjności kraju. Wysoka relacja kursu rynkowego do

21 Zob. M. Porter, Porter o konkurencji, PWE, Warszawa 2001, s. 34.

22 Zob. L. Lipschitz, D. McDonald, Real Exchange Rates and Competitiveness: A Clarification of Concepts and Some Measurements for Europe, IMF Working Paper 91/25 (1991), s. 5-8.

${ }_{23}$ Zob. M. Schmitz i in., Revisting the Effective Exchange Rates of the Euro, ECB Occasional Paper 134, 2012, s. 9. 
kursu wyliczanego na podstawie parytetu siły nabywczej oznacza wysoką konkurencyjność, a wzrost tej relacji oznacza wzrost konkurencyjności, oczywiście, pod warunkiem że zmiana ta ma charakter trwały.

W konsekwencji powyższych rozważań, w charakterze zagregowanego miernika konkurencyjności kraju można zaproponować długookresową (a więc mierzoną w perspektywie 10 lat) relację rynkowego kursu waluty wobec dolara US, do kursu wyliczanego według parytetu siły nabywczej (co w uproszczeniu oznacza hipotetyczny kurs waluty odpowiadający jej sile nabywczej, gdyby ceny w kraju były identyczne z cenami w USA ${ }^{24}$ ). Alternatywnie, ten sam wskaźnik można wyliczyć, dzieląc wartość PKB przeliczonego na dolary US według bieżącego kursu walutowego przez wartość PKB wyrażonego w dolarach według parytetu siły nabywczej (dane dotyczące PKB oraz szacunek wartości PKB według parytetu siły nabywczej, wraz z komentarzem metodologicznym, publikowane są corocznie przez Międzynarodowy Fundusz Walutowy, MFW'25).

Wartość tak zdefiniowanego wskaźnika konkurencyjności, uzyskany przy jego zastosowaniu ranking konkurencyjności krajów w roku 2017 (dokonany jedynie w odniesieniu do gospodarek krajów z ponad 1 mln mieszkańców i pokazany tylko dla pierwszych 30 pozycji), a także kluczowe charakterystyki makroekonomiczne gospodarek przedstawiono w tabeli 2.

Wartość wskaźnika kształtuje się między 0,24 w Myanmarze a 1,43 w Szwajcarii. Należy zauważyć, że zaproponowany pomiar ujawnionej konkurencyjności (ex post) daje wyniki pod wieloma względami zbliżone do pomiaru ex ante. Spośród krajów, które zajęły 20 pierwszych miejsc w rankingu, 16 znajdowało się też w pierwszej dwudziestce rankingu WEF. Jedyne dwa kraje z czołówki rankingu WEF, które wyraźnie przesunęły się w dół, to Singapur i Hongkong, a więc kraje stosujące od lat systematyczną politykę sztucznego osłabiania siły swych walut poprzez gromadzenie ogromnych rezerw walutowych ${ }^{26}$.

Po drugie, warto zauważyć, że państwa znajdujące się w czołówce zaproponowanego rankingu konkurencyjności charakteryzują się pewnymi wspólnymi cechami: wysokim na tle reszty świata poziomem dochodów (zwłaszcza przy pomiarze według bieżącego kursu walut) oraz (z wyjątkiem Japonii) umiarkowanym poziomem zadłużenia.

Należy też stwierdzić, że przy zastosowaniu zaproponowanego pomiaru ocena konkurencyjności Polski obniża się w stosunku do mierników WEF i IMD (48 miejsce, wobec 33-34 miejsca). Można to zinterpretować w taki sposób, że konkurencyjność rzeczywiście odnotowana przez Polskę jest niższa, niż wy-

${ }^{24}$ Szersze informacje o metodzie wyliczania takiego kursu zawiera praca: M. Silver, IMF Applications of Purchasing Power Parity Estimates, IMF Working Papers WP/10/253, 2010, https://doi.org/10.5089/9781455209538.001.

25 Zob. International Monetary Fund, Cyclical Upswing, Structural Change, „World Economic Outlook" April 2018, http://dx.doi.org/10.5089/9781484352618.081.

${ }^{26}$ Zob. W.M. Orłowski, Świat do przeróbki, op. cit., s. 214-215. 
Tabela 2. Podstawowe charakterystyki gospodarek krajów z czołówki rankingu konkurencyjności

\begin{tabular}{|c|c|c|c|c|c|c|c|c|}
\hline & & & & $\begin{array}{l}\text { PKB per co } \\
\text { (w tys. do }\end{array}$ & $\begin{array}{l}\text { pita, } 2017 \\
\text { larów US) }\end{array}$ & $\begin{array}{r}\text { Wskaźni } \\
\text { now }\end{array}$ & $\begin{array}{l}\text { niezrów- } \\
\text { zenia }\end{array}$ & \\
\hline & Kraj & $\begin{array}{c}\text { Wskaź- } \\
\text { nik } \\
\text { konku- } \\
\text { rencyj- } \\
\text { ności* }\end{array}$ & $\begin{array}{l}\text { Ludność, } \\
2017 \\
\text { (w mln) }\end{array}$ & $\begin{array}{c}\text { wg pary- } \\
\text { tetu siły } \\
\text { nabyw- } \\
\text { czej }\end{array}$ & $\begin{array}{c}\text { wg } \\
\text { bieżące- } \\
\text { go kursu } \\
\text { waluty }\end{array}$ & $\begin{array}{c}\text { dług } \\
\text { publicz- } \\
\text { ny (w \% } \\
\text { PKB) } \\
2017\end{array}$ & $\begin{array}{c}\text { saldo } \\
\text { obrotów } \\
\text { bieżą- } \\
\text { cych } \\
\text { (w \% } \\
\text { PKB) } \\
2017 \\
\end{array}$ & $\begin{array}{c}\text { Stopa } \\
\text { wzrostu } \\
\text { eks- } \\
\text { portu, } \\
2000- \\
2017\end{array}$ \\
\hline 1 & Szwajcaria & 1,4 & 8,4 & 61,4 & 80,6 & 42,8 & 9,3 & 7,3 \\
\hline 2 & Norwegia & 1,4 & 5,3 & 71,8 & 74,9 & 36,7 & 5,1 & 3,0 \\
\hline 3 & Dania & 1,3 & 5,7 & 49,9 & 56,4 & 36,4 & 7,6 & 5,1 \\
\hline 4 & Australia & 1,3 & 24,8 & 50,3 & 55,7 & 41,6 & $-2,3$ & 7,0 \\
\hline 5 & Szwecja & 1,2 & 10,1 & 51,5 & 53,2 & 40,9 & 3,2 & 4,4 \\
\hline 6 & Finlandia & 1,2 & 5,5 & 44,3 & 46,0 & 61,4 & 0,7 & 3,1 \\
\hline 7 & Kanada & 1,1 & 36,7 & 48,3 & 45,1 & 89,7 & $-3,0$ & 2,3 \\
\hline 8 & Japonia & 1,1 & 126,7 & 42,8 & 38,4 & 236,4 & 4,0 & 2,8 \\
\hline 9 & Nowa Zelandia & 1,1 & 4,8 & 38,9 & 41,6 & 26,4 & $-2,7$ & 6,2 \\
\hline 10 & Irlandia & 1,1 & 4,7 & 75,5 & 70,6 & 68,5 & 12,5 & 7,3 \\
\hline 11 & Wielka Brytania & 1,1 & 66,1 & 44,1 & 39,7 & 87,0 & $-4,1$ & 3,8 \\
\hline 12 & Francja & 1,1 & 64,8 & 43,8 & 39,9 & 97,0 & $-1,4$ & 4,1 \\
\hline 13 & Austria & 1,1 & 8,8 & 49,9 & 47,3 & 78,8 & 2,1 & 2,9 \\
\hline 14 & Belgia & 1,1 & 11,4 & 46,6 & 43,6 & 103,2 & 0,1 & 3,3 \\
\hline 15 & Izrael & 1,1 & 8,7 & 36,3 & 40,3 & 61,0 & 3,0 & 4,6 \\
\hline 16 & Holandia & 1,1 & 17,1 & 53,6 & 48,3 & 56,7 & 9,8 & 6,1 \\
\hline 17 & Niemcy & 1,0 & 82,7 & 50,4 & 44,5 & 64,1 & 8,0 & 6,3 \\
\hline 18 & USA & 1,0 & 325,9 & 59,5 & 59,5 & 107,8 & $-2,4$ & 4,6 \\
\hline 19 & Włochy & 1,0 & 60,6 & 38,1 & 32,0 & 131,5 & 2,9 & 4,1 \\
\hline 20 & Hiszpania & 0,9 & 46,3 & 38,3 & 28,4 & 98,4 & 1,7 & 5,6 \\
\hline 21 & Grecja & 0,8 & 10,8 & 27,7 & 18,6 & 181,9 & $-0,8$ & 4,0 \\
\hline 22 & Portugalia & 0,8 & 10,3 & 30,4 & 21,2 & 125,6 & 0,5 & 5,9 \\
\hline 23 & Słowenia & 0,8 & 2,1 & 34,4 & 23,7 & 75,4 & 6,5 & 7,7 \\
\hline 24 & Puerto Rico & 0,8 & 3,2 & 37,3 & 30,5 & 54,6 & 0,0 & 6,2 \\
\hline 25 & Korea Płd. & 0,7 & 51,5 & 39,4 & 29,9 & 39,8 & 5,1 & 7,1 \\
\hline 26 & Urugwaj & 0,7 & 3,5 & 22,4 & 16,7 & 66,2 & 1,6 & 9,1 \\
\hline 27 & Hongkong & 0,7 & 7,4 & 61,4 & 46,1 & 0,1 & 3,0 & 6,6 \\
\hline 28 & Brazylia & 0,7 & 207,7 & 15,6 & 9,9 & 84,0 & $-0,5$ & 8,0 \\
\hline 29 & Estonia & 0,7 & 1,3 & 31,7 & 19,8 & 8,8 & 3,2 & 10,9 \\
\hline 30 & Kostaryka & 0,7 & 5,0 & 16,9 & 11,7 & 49,1 & $-3,1$ & 6,9 \\
\hline 48 & Polska & 0,6 & 38,0 & 29,5 & 13,8 & 51,4 & 0,0 & 11,0 \\
\hline
\end{tabular}

* Relacja bieżącego kursu walutowego do siły nabywczej waluty, średnio w latach 2008-2017. Źródło: MFW, Bank Światowy. 
Wykres 1. Ranking według wskaźnika konkurencyjności a wielowymiarowa ocena konkurencyjności ex ante (2017)

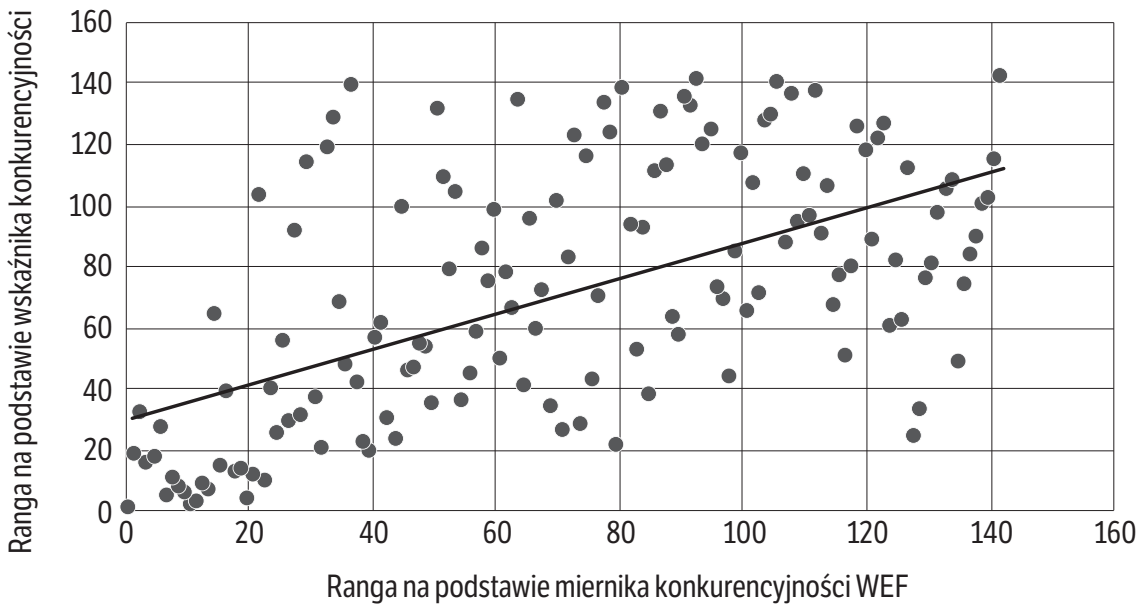

Źródło: na podstawie danych z Banku Światowego, MFW, WEF.

nikałoby z ocen ex ante - innymi słowy, że Polska nie wykorzystuje w pełni możliwości wzrostu swojej konkurencyjności, na które pozwala obecny rozwój instytucjonalny i gospodarczy. Ma to szczególne znaczenie w kontekście dyskusji nad modelem rozwojowym kraju, wskazując wyraźnie na słabą stronę dotychczasowego modelu, w znacznej mierze opartego na stosunkowo niskim koszcie pracy ${ }^{27}$. Krótkookresowo model taki pozwala utrzymać bieżącą konkurencyjność eksportu poprzez stosunkowo niskie płace, jednak szybszy wzrost płac (który wynika z niskiego bezrobocia) spowodowałby kompensujące go osłabienie waluty. Warunkiem uniknięcia tego zjawiska jest poprawa omówionych wyżej fundamentalnych czynników, decydujących na dłuższą metę o konkurencyjności kraju.

$\mathrm{Na}$ wykresie 1 pokazano związek istniejący między oceną konkurencyjności ex ante dokonaną na podstawie miernika WEF, a oceną ex post na podstawie zaproponowanego wskaźnika, zaobserwowany dla 142 krajów objętych obu pomiarami. Daje się zauważyć statystycznie istotną dodatnią korelację obu wskaźników (współczynnik korelacji wynosi 0,58), co oznacza, że wysoki rozwój instytucjonalny i gospodarczy kraju (mierzony wskaźnikiem ex ante) daje możliwość osiągnięcia wysokiej ujawnionej pozycji konkurencyjnej (mierzonej expost). Oczywiście, możliwość ta nie oznacza wcale determinizmu - z istniejącej szansy można nie skorzystać (np. prowadząc sprzeczną z rynkowymi trendami politykę gospodarczą), można też odnotować wyniki czasowo lepsze od oczekiwań (np. sztucznie podtrzymując wartość krajowej waluty poprzez systematyczne zadłużanie się;

27 Zob. J. Bossak, Międzynarodowa konkurencyjność gospodarki, op. cit., s. 38-39. 
jednak takiej polityki nie daje się stosować w nieskończoność). Szerokie pole do dalszych badań daje analiza czynników, które powodują wyraźne różnice w pozycji krajów w rankingu konkurencyjności ex ante i ex post. Warto też zauważyć, że przy wszystkich zastrzeżeniach co do wiarygodności analizy jest to faktycznie pierwsza statystyczna weryfikacja wielowymiarowego wskaźnika konkurencyjności stworzonego przez WEF (konkurencyjność mierzona ex ante rzeczywiście prowadząca, w istotny statystycznie sposób, do konkurencyjności ex post).

Na wykresie 2 pokazano z kolei dość ścisły związek między pomiarem konkurencyjności a stopniem rozwoju kraju i poziomem dochodów jego mieszkańców mierzonym według bieżącego kursu walutowego. Relacja ta jest bardzo silna (współczynnik korelacji wynosi 0,86), co dowodzi bezpośredniego związku między wartością miernika, a wymaganą na podstawie sformułowanej powyżej definicji zdolnością wysoko konkurencyjnej gospodarki do zapewnienia wysokich dochodów swoich mieszkańców. Wiąże się to oczywiście zarówno z realną, wysoką produktywnością, jak też z wysoką wyceną jednostki pracy danego kraju przez globalny rynek (nakładanie się na siebie obu tych czynników potwierdza fakt, że współczynnik korelacji, mierzony między wskaźnikiem konkurencyjności a samą tylko realną produktywnością mierzoną przez PKB według parytetu siły nabywczej, jest niższy i wynosi 0,63 ).

Wykres 2. Ranking według wskaźnika konkurencyjności a bieżące dochody mieszkańców (2017)

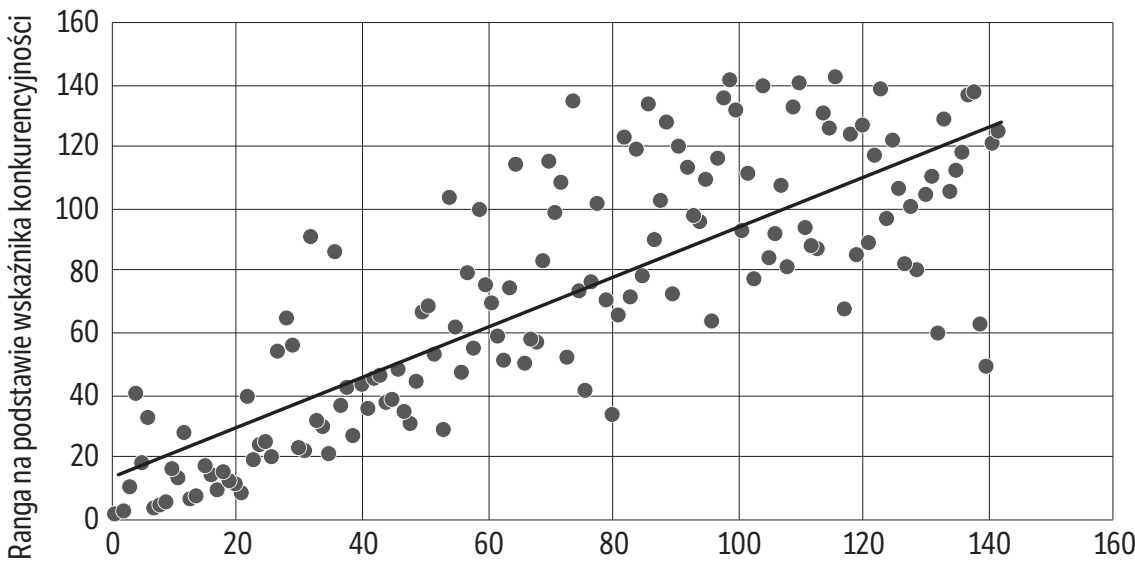

Ranga na podstawie PKB na głowę mieszkańca wg bieżących kursów walut

Źródło: na podstawie danych MFW.

Na wykresie 3 przedstawiono wreszcie relację między oceną konkurencyjności ex post na podstawie zaproponowanego wskaźnika a miernikiem jakości instytucji. W charakterze miernika rozwoju instytucji przyjęto publikowany przez 
Bank Światowy ranking Doing Business, oceniający, na ile rozwinięte, sprawne i przyjazne rynkowi są instytucje w poszczególnych krajach ${ }^{28}$. Należy jednak zauważyć, że oceny prezentowane w tym raporcie są w pewien sposób obciążone: badanie, oparte na pomiarze kilkudziesięciu wskaźników (m.in. poprzez prowadzone w poszczególnych krajach bezpośrednie eksperymenty ustalające długotrwałość biurokratycznych procedur), w wyraźny sposób uznaje za modelowe liberalne rozwiązania anglosaskie. W efekcie tego kraje o anglosaskiej kulturze prawnej nieodmiennie zajmują czołowe miejsca rankingu, podczas gdy np. kraje o niemieckiej kulturze prawnej (Niemcy, Austria, Szwajcaria) lokują się dopiero w drugiej i trzeciej dziesiątce, jako kraje silnie przeregulowane. Mimo tych wad badanie Doing Business jest powszechnie uważane za dość wiarygodną ocenę rozwoju instytucjonalnego gospodarek. Pomiędzy mierzonym w ten sposób stopniem rozwoju instytucjonalnego a miernikiem ujawnionej konkurencyjności istnieje również wyraźna dodatnia zależność (współczynnik korelacji wynosi 0,62).

Wykres 3. Ranking według wskaźnika konkurencyjności a jakość otoczenia instytucjonalnego (2017)

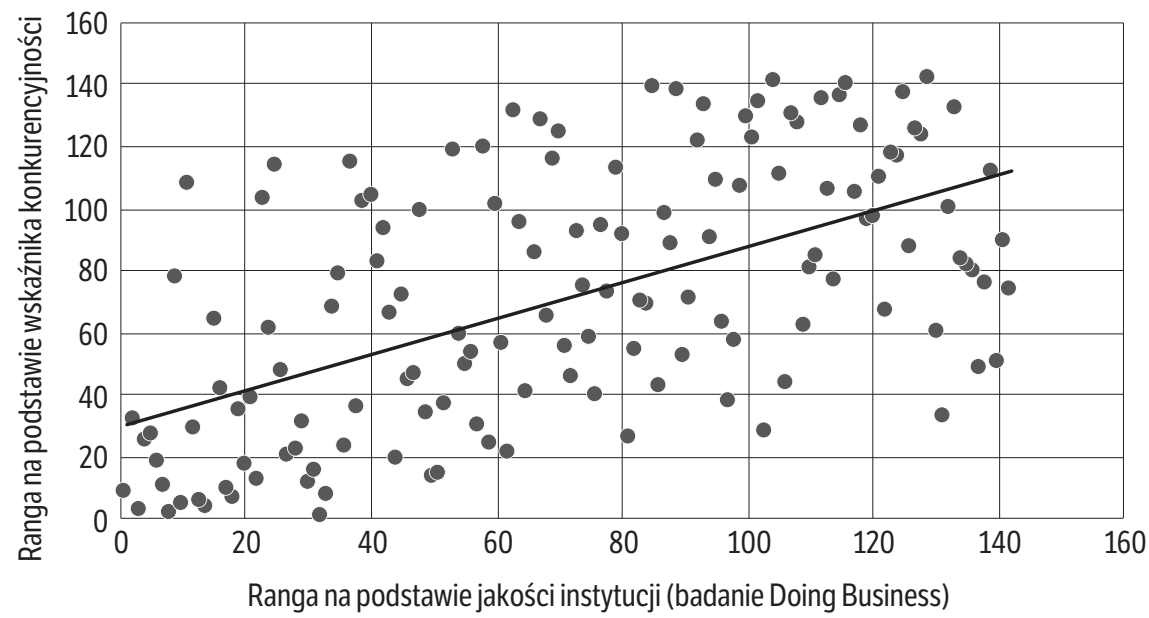

Źródło: na podstawie danych Banku Światowego, MFW.

\section{Zastrzeżenia dotyczące zaproponowanego wskaźnika}

Zaproponowany wskaźnik pomiaru ex post konkurencyjności krajów ma oczywiście wiele zalet: jest prosty, dobrze osadzony w teorii ekonomii, a przeprowadzona wyżej analiza pokazuje, że generuje on wyniki w znacznej mierze zgodne z intuicją.

Z drugiej strony ma jednak również swoje wady i słabości.

28 Zob. World Bank, Doing Business 2017. Equal Opportunity for All, World Bank, Washington 2017, https://doi.org/10.1596/978-1-4648-0948-4. 
Pierwsza $\mathrm{z}$ nich wynika $\mathrm{z}$ faktu jego zagregowanego i prostego charakteru. Jest oczywiste, że przy takiej konstrukcji nie jest on w stanie wychwycić wszystkich ważnych czynników, które krótkookresowo, a nawet w średnim okresie, mogą wpływać na obserwowaną pozycję konkurencyjną kraju. Przykładowo, kraj dysponujący bardzo dużymi zasobami naturalnymi może dzięki temu osiągnąć pozornie wysoką konkurencyjność, gwałtownie zwiększając swoje dochody eksportowe, a w ślad za tym doświadczając aprecjacji waluty i silnego wzrostu dochodów ludności (przykładem takiego zjawiska była Rosja w latach 2000-2008). Innym przykładem jest możliwość pozornego wzrostu mierzonego za pomocą zaproponowanego wskaźnika konkurencyjności przez kraj, który gwałtownie zapożycza się za granicą, dzięki czemu jest w stanie wbrew długookresowym fundamentom rynkowym wzmocnić rynkową wartość swojej waluty (jak kraje śródziemnomorskie Unii Europejskiej oraz kraje bałtyckie w latach 2000-2008). Odwrotnością tej sytuacji jest polityka gromadzenia wielkich rezerw walutowych, utrzymująca rynkową wartość waluty poniżej jej oczekiwanego poziomu (stosowana latami np. przez Chiny oraz powiązane z nimi gospodarki Azji Południowo-Wschodniej). Oczywiście prędzej czy później takie sztuczne podniesienie lub obniżenie wskaźnika konkurencyjności musi się zakończyć. W krajach opierających wysokie dochody na eksploatacji zasobów naturalnych następuje to po spadku rynkowych cen surowców, przy czym nawet w okresie surowcowego boomu pozycja konkurencyjna kraju jest osłabiana przez efekty tzw. choroby holenderskiej (polega ona na tym, że sztuczne wzmocnienie rynkowego kursu waluty szkodzi konkurencyjności pozostałych gałęzi gospodarki, przede wszystkim przemysłu przetwórczego ${ }^{29}$ ). Z kolei w krajach nadmiernie zadłużających się w którymś momencie następuje zmiana rynkowych ocen sytuacji finansowej i ucieczka kapitału, prowadząca do ponownego osłabienia waluty lub wręcz kryzysu ${ }^{30}$. Kraje sztucznie osłabiające swoją walutę również napotykają kłopoty związane z nadmierną akumulacją rezerw walutowych, choć akurat w tym wypadku przy odpowiedniej determinacji możliwa jest długotrwała kontynuacja takiej polityki ${ }^{31}$.

Drugim, znacznie poważniejszym zastrzeżeniem, które można przedstawić, jest to, że zaproponowany miernik konkurencyjności bazujący na porównaniu kursu rynkowego i opartego na parytecie siły nabywczej odpowiada sformułowanej wyżej definicji konkurencyjności tylko wtedy, gdy uwzględnia fakt, że zapewnienie wysokich dochodów musi mieć charakter trwały. Przyjęty przy wyliczeniu wskaźnika okres 10-letni niestety nie zawsze będzie wystarczający dla zapewnienia takiej trwałości pozycji kraju. Zagrożenia dla trwałości mogą

29 Zob. L. Lipschitz, D. McDonald, Real Exchange Rates and Competitiveness, op. cit., s. $14-15$.

${ }^{30}$ Zob. M. Schmitz i in., Revisting the Effective Exchange Rates, op. cit., s. 27.

31 Zob. W.M. Orłowski, Świat do przeróbki, op. cit., s. 214. 
wynikać z wielu przyczyn, wśród których niebagatelną i przyciągającą coraz większą uwagę jest aspekt społeczny ${ }^{32}$. W krajach, w których wysokiemu obserwowanemu poziomowi konkurencyjności towarzyszy np. bardzo wysoki wzrost zróżnicowania dochodowego, możliwe są gwałtowne wstrząsy polityczne i społeczne, które mogą doprowadzić do silnej destabilizacji (podobny efekt mogą oczywiście mieć konflikty zbrojne, wewnętrzne i zewnętrzne).

Z ekonomicznego punktu widzenia ważniejsze jednak wydaje się zagrożenie wynikające z długotrwałego, sztucznego zawyżenia wskaźników konkurencyjności spowodowanego wieloletnim zadłużaniem się krajów. Jak już wcześniej napisano, w normalnych warunkach polityka taka nie ma raczej szans na długo uciec uwadze uczestników rynku. W obecnym wieku mieliśmy jednak np. możliwość zaobserwowania anormalnych zachowań rynkowych związanych z pierwszymi latami funkcjonowania strefy euro. Wobec łatwego dostępu krajów śródziemnomorskich do taniego kapitału (płacone przez nie niskie stopy procentowe były pozornie „zabezpieczone” faktycznie nieistniejącymi gwarancjami ze strony największych krajów strefy ${ }^{33}$ ), a w pewnym stopniu również w prowadzących politykę stałego kursu walutowego krajów bałtyckich, powstała pokusa do nieprzejmowania się konsekwencjami wzrostu długu ${ }^{34}$. W efekcie w krajach tych wzrosła inflacja, ale brak możliwości dostosowania rynkowego kursu walutowego powodował stałość wskaźnika konkurencyjności. To ostatnie zjawisko było jednak mylące, bowiem pozornemu utrzymywaniu się wysokiej wyceny pracy towarzyszył pogłębiający się dramatycznie deficyt w wymianie z zagranicą, który w końcu doprowadził do głębokiego kryzysu i ponownego obniżenia deficytu przez programy oszczędnościowe - tym ostrzejsze, im większy był ich pierwotny wzrost.

\section{Podsumowanie}

Problematyka konkurencyjności gospodarczej krajów ma ogromne znaczenie dla właściwej oceny sytuacji ekonomicznej i dla prowadzenia właściwej polityki gospodarczej we współczesnym świecie. Niestety, problemem jest już to, że pojęcie to nie jest jasno i precyzyjnie zdefiniowane, a stosowane do jego pomiaru mierniki budzą liczne wątpliwości. Najbardziej dziś popularne mierniki oparte na wyciąganiu średniej z bardzo dużej liczby danych statystycznych i wyników badań ankietowych, służące do sporządzania szeroko dyskutowanych rankingów konkurencyjności, mają wiele wad. Nie są oparte na jasnym modelu teoretycznym, a w ich konstrukcji razi uznaniowość, mająca poważny wpływ na uzyskanie wyniki. Zdaje się jednak, że jesteśmy na nie skazani, choć warto

${ }^{32}$ Zob. World Economic Forum, The Global Competitiveness Report 2017-2018, op. cit.

${ }_{33}$ Zob. M. Schmitz i in., Revisting the Effective Exchange Rates, op. cit., s. 28-29.

${ }^{34}$ Zob. W.M. Orłowski, Świat do przeróbki, op. cit., s. 160. 
poszukiwać innych mierników, które w bardziej obiektywny sposób pozwalałyby dokonać oceny.

Zaproponowany w artykule wskaźnik, oparty na porównaniu wyceny jednostki pracy przez rynek globalny i przez rynek krajowy, ma oczywiście również wady. Jest jednak próbą innego spojrzenia na pomiar konkurencyjności, a uzyskane na jego podstawie wyniki prowadzą do sformułowania hipotezy, że obserwowana obecnie pozycja konkurencyjna Polski jest słabsza niż wynikałoby to z pozio$\mathrm{mu}$ rozwoju instytucjonalnego i gospodarczego kraju. Jest to szczególnie ważne z punktu widzenia toczonej obecnie dyskusji na temat modelu rozwojowego Polski, a w szczególności na temat ryzyka utknięcia kraju w tzw. pułapce średniego rozwoju ${ }^{35}$. Stosunkowo niski poziom konkurencyjności, mierzony zaproponowanym wskaźnikiem, wyraźnie wskazuje na silne opieranie rozwoju na atucie taniej pracy. Pułapka średniego rozwoju oznacza sytuację, w której - przy takim właśnie modelu rozwoju - wzrost kosztów pracy powoduje utratę bieżącej konkurencyjności rynkowej eksportowanych towarów, co prowadzi do osłabienia się waluty i przywrócenia w ten sposób niskiej wyceny pracy w danym kraju przez rynek globalny. Jedynym sposobem wyrwania się z tej pułapki jest poprawa fundamentalnych czynników decydujących o konkurencyjności, a więc produktywności, innowacyjności, używanych technologii oraz miejsca w łańcuchu wartości ${ }^{36}$, co powinno prowadzić do trwałego wzrostu wyceny pracy i tym samym wzrostu wartości zaproponowanego wskaźnika. Poprawie tej służyć może odpowiednia polityka przemysłowa, ale w jeszcze większym stopniu tworzenie warunków rynkowych zachęcających do intensywnego inwestowania, poszukiwania innowacji $\mathrm{i}$ awansu polskich przedsiębiorstw w globalnym łańcuchu wartości.

Jeśli prawdą jest, że pozycja konkurencyjna Polski jest obecnie wyraźnie słabsza niż wynikałoby to z poziomu rozwoju instytucjonalnego i gospodarczego, oznaczałoby to niepełne wykorzystanie przez Polskę posiadanych atutów. Stanowiłoby więc zachętę do krytycznego przyjrzenia się modelowi rozwojowemu opartemu na niskim koszcie pracy i prowadzonej przez nasze państwo w tym zakresie polityki.

\section{Literatura cytowana}

Agénor P., Canuto O., Jelenic M., Avoiding Middle-Income Growth Traps, „Economic Premise" 2012, nr 98.

Annoni P., Dijkstra L., Gargano N., The EU Regional Competitiveness Index 2016, European Commission Working Papers WP 02/2017.

35 Zob. P. Agénor, O. Canuto, M. Jelenic, Avoiding Middle-Income Growth Traps, „Economic Premise" 2012, nr 98.

${ }_{36}$ Zob. M. Porter, C. Ketels, M. Delgado, The Microeconomic Foundations of Prosperity, op. cit., s. 52-55. 
Bossak J., Międzynarodowa konkurencyjność gospodarki polskiej - ujęcie instytucjonalne [w:] Konkurencyjność gospodarki polskiej a rola państwa przed akcesja do Unii Europejskiej, red. H. Podedworny, J. Grabowiecki, H. Wnorowski, Uniwersytet w Białymstoku, Białystok 2000.

D’Andrea Tyson L., Who's Bashing Whom: Trade Conflict in High Technology Industries, Institute for International Economics, Washington 1992.

Gittleson K., US trade: Is Trump right about the deficit?, BBC News, 2018, https://www. bbc.com/news/world-43336599.

International Institute for Management Development, World Competitiveness Yearbook 2017, IMD Publishing, Lausanne 2017.

International Monetary Fund, Cyclical Upswing, Structural Change, „World Economic Outlook" April 2018, http://dx.doi.org/10.5089/9781484352618.081.

Jorgenson D.W., Kuroda M., Productivity and International Competitiveness in Japan and the United States, 1960-1985 [w:] International Productivity and Competitiveness, red. B.G. Hickman, Oxford University Press, New York 1992.

Krugman P., Making Sense of the Competitiveness Debate, „Oxford Review of Economic Policy" 1996, nr 12(3).

Lipschitz L., McDonald D., Real Exchange Rates and Competitiveness: A Clarification of Concepts and Some Measurements for Europe, IMF Working Paper nr 91/25.

Mróz J., Determinanty i miary międzynarodowej konkurencyjności gospodarki [w:] Ekonomia i zarzadzanie w teorii i praktyce, t. 9, red. P. Urbanek, E. Walińska, Wydawnictwo Uniwersytetu Łódzkiego, Łódź 2016.

Orłowski W.M., Makroekonomiczne przyczyny deficytu obrotów bieżących [w:] Bilans płatniczy Polski. Wyzwania i zagrożenia, red. U. Płowiec, W.M. Orłowski, Bellona, Warszawa 1999.

Orłowski W.M., Świat do przeróbki, Agora, Warszawa 2011.

Porter M., Porter o konkurencji, PWE, Warszawa 2001.

Porter M., Ketels C., Delgado M., The Microeconomic Foundations of Prosperity: Findings from the Business Competitiveness Index [w:] The Global Competitiveness Report 2007-2008, World Economic Forum, Geneva 2008.

Radło M.J., Międzynarodowa konkurencyjność gospodarki. Uwagi na temat definicji, czynników i miar, Oficyna Wydawnicza SGH, Warszawa 2008.

Schmitz M. i in., Revisting the Effective Exchange Rates of the Euro, ECB Occasional Paper 134 (2012).

Silver M., IMF Applications of Purchasing Power Parity Estimates, IMF Working Papers WP/10/253 (2010), https://doi.org/10.5089/9781455209538.001.

Siudek T., Zawojska A., Competitiveness in the economic concepts, theories and empirical research, „Acta Scientiarum Polonorum. Oeconomia” 2014, nr 13(1).

Voinescu R., Moisoiu C., Competitiveness, Theoretical and Policy Approaches. Towards a more competitive EU, „Procedia Economics and Finance” 2015, nr 22, https://doi. org/10.1016/s2212-5671(15)00248-8. 
Wojtyna A., O badaniach nad „głębszymi” przyczynami wzrostu gospodarczego [w:] Wzrost gospodarczy w krajach transformacji. Konwergencja czy dywergencja?, red. R. Rapacki, PWE, Warszawa 2009.

World Bank, Doing Business 2017. Equal Opportunity for All, World Bank, Washington 2017, https://doi.org/10.1596/978-1-4648-0948-4.

World Economic Forum, The Global Competitiveness Report 2017-2018, red. X. Sala-i-Martín, K. Schwab, World Economic Forum, Geneva 2017. 